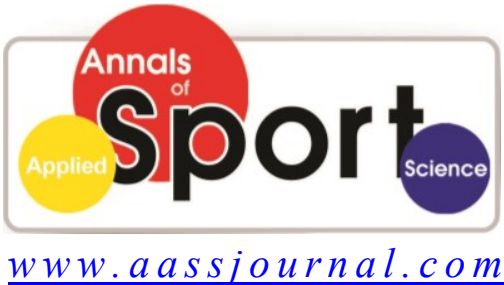

ISS N (Online): $2322-4479$

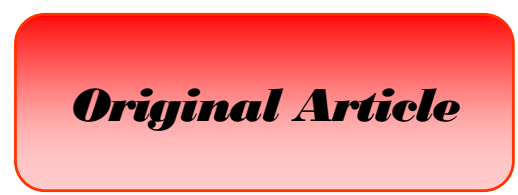

Received: 03/07/2014

Accepted: 20/10/2014

\title{
The Relationship between Knowledge Management and the Process of Entrepreneurship in Sport Organizations
}

\section{${ }^{1}$ Taghi Ashouri*, ${ }^{2}$ Mohammad Reza Boroumand}

1. Department of Sport Management, Mazandaran University, Babolsar, Iran.

2. Department of Sport Management, Shahid Beheshti University, Tehran, Iran.

\section{ABSTRACT}

In the current competitive world, organizations can reach competitive advantage which support entrepreneurship by providing the required tools. One of the most important tools for developing entrepreneurship which was neglected in previous studies is organizational knowledge management. The present paper aims to shed light on the role and importance of knowledge management in sport entrepreneurship in sport organizations of Mazandaran Province. 250 managers and employees of sport organizations were selected as the sample. Two questionnaires were used for data collection; knowledge management questionnaire with 22 questions (including knowledge acquisition, knowledge creation, knowledge storage, knowledge sharing, and knowledge application) and entrepreneurship questionnaire with 35 questions (including idea creation, opportunity discovery, and idea exploitation). The results show that there is a significant relation between knowledge management and entrepreneurship process $(\mathrm{r}=0.68, \mathrm{p}=0.001)$ and also between knowledge management and entrepreneurship components (idea creation: $r=0.33, p=0.001$; opportunity discovery: $r=0.53, p=0.001$; idea exploitation: $r=0.33, p=0.001$ ). According to the results, paying attention to knowledge management can systematically support the organizations in idea creation, opportunity discovery from created ideas, idea exploitation, and also entrepreneurship. Managers of sport organizations should assume that knowledge management is one of the empowerments of entrepreneurship or, in other words, knowledge management is one of the effective factors in the emergence of entrepreneurship. Hence, knowledge management should be regarded as one of main priorities and special planning must be done for it.

Key Words: Entrepreneurship, Idea Creation, Opportunity Discovery, Idea Exploitation, Sport Organizations, Innovation.

Corresponding Author:

Taghi Ashouri

E-mail: t.ashouri86@yahoo.com 


\section{INTRODUCTION}

During the past two decades, managers have witnessed a period of dramatic global changes such as increased competition, global competition, shorter shelf time of products, rising customer expectations, and low ability to raise prices even in products with high demand. These changes are rooted in the rise of the global economy, global business, and move from the industrial community to the information-centered era $(1,2)$. Hence, knowledge has become an essential asset and potential and it is important to know how employ various knowledge sources and manage them for survival in today's competitive world $(3,4)$. The phrase 'knowledge is power' has been supplanted by the phrase "knowledge sharing is power" in the era of wisdom (5), as knowledge replaced physical and financial assets (5-7).

The importance of the fact that organizations need more entrepreneurial activities is on the rise (8) and according to Mosaheb and Khaksar (2014), it is affected by factors such as the rapid increase of new competitors, a sense of distrust in traditional management practices in organizations, and the leave of organizations by the best labor force to set up their own entrepreneurial activities (9). Madhoshi et al. (2011) defines entrepreneurship as discovery, evaluation, and exploitation of opportunities (10). Accordingly, idea-processing refers to the expression of thought, conscience, and imagination for innovation within the organization. Since the all generated ideas are not valuable for an organization, organizations assess the feasibility of ideas. Opportunity discovery or evaluation of ideas is a process through which the value of ideas are determined. In fact, opportunity discovery determines that whether an idea could be a business opportunity or not. When the idea is identified as an opportunity, it is used by the organization in products, services, and processes. In fact, the use or ideas exploitation means to design, construct, test, and commercialize an idea to be used in products, services, and processes (11). This means new products, services or production processes, new organizational forms and strategies, new markets for products, and inputs that were not previously available (12). In today's unstable environment, organizations can no longer expect that the products or services which previously led them to success pave the way for their future success and prosperity (13), because the main differentiating factor and competitive advantage of organizations in the era of communication and information technology is their more knowledge and information compared with their competitors. On the other hand, organizations are faced with rivals which have a good performance in areas such as planning, marketing, products, customer service, structure, and management of organizational resources. Effective knowledge management may be the only weapon to win this competition $(14,15)$. Generally, entrepreneurs in our country develop their own business or skill through trial and error. Those who see the ability in themselves to set out new businesses explore the existing opportunities in the community, conduct a technical and economic opportunity discovery, mobilize the scattered financial and human resources, achieve the related technologies, and finally take the risk of failure to enter the market of business. Among this group of entrepreneurs, only a few ones usually leave behind the risk of early failure and go to the more advanced stages of their business. The entrepreneurs who enter the arena of business in such a way usually do not enjoy special training other than those learned in their previous jobs (16). Knowledge can play the role of a catalyst in skills of entrepreneurs and shorten the way that they may pass with trial and error after a long time through equipping them with 
specific knowledge and skills and quickly make an experienced entrepreneur out of a potential one. Radfar, Rezaeimalek, and Rezaeimalek (2015) studied the impact of a knowledge management system on improvement of financial performance in a private company and reported that a knowledge management system can improve the financial performance of a company by $70 \%$ (17). Vazifehdust, Foroughnejad, and Khoshnood (2014) showed that codified knowledge management strategies can directly or indirectly affect the performance of brokerage firms in Tehran Stock Exchange through enhancing the capability of innovation (18). Raesi et al. (2014) and Omidi, Tondnevis, and Mozafari (2013) reported the relationship between knowledge management and effectiveness in sport organizations $(19,20)$. Nasrollahi et al. (2013) stated that knowledge management includes three components of knowledge creation, knowledge transfer, and application of knowledge and confirmed the relationship between knowledge management and organizational entrepreneurship in the General Directorate of Youth and Sport of Khuzestan Province (21). They also showed that knowledge transfer and application of knowledge have a significant relationship with entrepreneurship. Khosravi and Esmaili (2013) carried out a study to identify the components of knowledge management and their effect on organizational entrepreneurship in the General Directorate of Social Security of Qom and found that there is a significant relationship between knowledge management (also its components) and organizational entrepreneurship (22).

As we know, in the Twenty-year Outlook Horizon of 1404, Iran as a leading Islamic country should have the first rank among the 26 countries in the Middle East in new knowledge - based products and services. This will not be realized without the support of knowledge - oriented entrepreneurs. Therefore, according to the position and importance of Mazandaran Province as the sports hub of Iran in national and international events and given the necessity and importance of sport entrepreneurship in economic development of this province, the present paper aims to study the status of entrepreneurship and its relationship with knowledge management in sport organizations of this province.

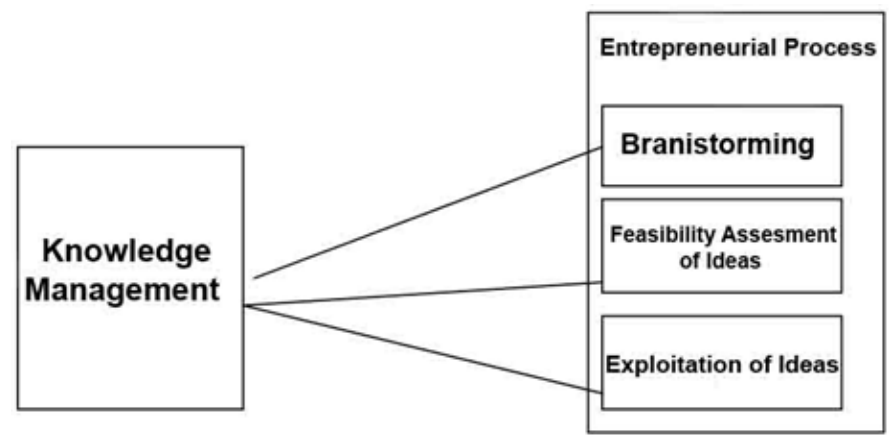

Figure 1: The conceptual model of research

\section{MATERIALS AND METHODS}

In terms of objective and data collection, the present study is considered, respectively, an applied and descriptive-correlation research. In addition, as the data are studied in a specific period, this study considered a cross-sectional research.

Participants. Statistical population included all employees of the General Directorate of Youth and Sport of 
Mazandaran Province (122 respondents), physical education managers of Education Directorate (17 respondents), and employees of sport committees of Mazandaran Province (111 respondents). 310 questionnaires were handed out among the sample that 250 of them were completely filled out. Among the 250 respondents, 167 people $(66.8 \%)$ were male and 83 people $(33.2 \%)$ were female. $127(50.8 \%), 84(33.6 \%), 22(8.8 \%)$, and 17 $(6.8 \%)$ of the respondents had a bachelor's degree, associate's degree, high school diploma, and a master's degree, respectively. Only $29 \%$ of the respondents (72 people) had an academic degree related to physical education.

Tools. The questionnaire used in this study was adapted from the questionnaire developed by Madhoshi and Sadati (2012) which includes 22 questions related to knowledge management (23). Entrepreneurship process questionnaire contained 35 questions. This questionnaire was previously used by Farhangi and Safarzadeh (2006) (24). Validity of these questionnaires were evaluated by academic professors and approved after some modifications. Cronbach's alpha coefficient test was also used to determine the reliability of these questionnaires. Cronbach's alpha used for knowledge management, entrepreneurship, brainstorming (idea creation), opportunity discovery, and idea exploitation, was $0.86,0.94,0.91,0.94$, and 0.752 , respectively.

Statistical Analysis. The collected data were analyzed using Kolmogorov-Smirnov and Pearson correlation coefficient test to examine the hypothesis of the study. Significance levels accepted at $p<0.05$. All statistical analyses were performed using Statistical Package for Social Sciences software.

\section{RESULTS}

Statistical analysis shows that the correlation coefficient between knowledge management and entrepreneurship process is significant $(r=0.68$, Sig. $=0.001)$. So, due to the high correlation coefficient, this relationship was confirmed at a good level (Table 1). Analyses indicate a direct relationship between these two variables in sport organizations of Mazandaran Province, at a level of $\mathrm{p}<0.05$.

Besides the correlation coefficient between knowledge management and opportunity discovery was significant $(\mathrm{r}=0.33$, Sig. $=$ 0.001) (Table 1).

Also, correlation coefficient between knowledge management and discovery of opportunities from the generated ideas was significant $(\mathrm{r}=0.53$, Sig. $=0.001)$ (Table 1$)$.

And so, analyses indicate that the correlation coefficient between knowledge management and ideas exploitation was significant $(r=0.33$, Sig. $=0.001)($ Table 2$)$.

Table 1: Correlation coefficient between knowledge management and entrepreneurship process

\begin{tabular}{cccc}
\hline Correlation of Knowledge Management and ... & $\mathrm{N}$ & $\mathrm{r}$ & Sig \\
\hline Entrepreneurship & 250 & 0.68 & $0.001^{*}$ \\
\hline Opportunity discovery & 250 & 0.33 & $0.001^{*}$ \\
\hline Idea Creation & 250 & 0.53 & $0.001^{*}$ \\
\hline Ideas Exploitation & 250 & 0.33 & $0.001^{*}$ \\
\hline *: Significant at $\mathrm{p}<0.05$. & & &
\end{tabular}

\section{DISCUSSION and CONCLUSION}

In the past, most researches have studied the relationship between knowledge management and creativity and their results showed that organizations should promote creativity for their survival and knowledge management can increase the production of ideas (25). However, the role and impact of 
knowledge management processes (acquisition, creation, storage, sharing, and application of knowledge) and entrepreneurship processes (idea creation, opportunity discovery, and idea exploitation) in sport organizations have not been studied directly. The present study theoretically state that organizational entrepreneurship and innovation does not mean only to generate ideas but it involves the sequential process of idea creation, discovery of opportunities, and ideas exploitation.

According to the results of hypotheses confirming the relationship between knowledge management and entrepreneurship process, sport organizations administrators should note that taking into account the functions of knowledge management can help their organizations in idea creation, discovery of opportunities, and ideas exploitation. Hence, managers should systematically support all processes of knowledge management for success in entrepreneurship. $\mathrm{Ju}, \mathrm{Li}$, and Lee (2006) emphasize this issue and believe that the processes of knowledge management are different parts of a chain that leads to idea creation, innovation, improved performance, and acquisition of a sustainable competitive advantage when these components systematically support each other (26).

The results of the present study are consistent with findings of Nasrollahi et al. (2013) and Madhoshi and Sadati (2012) (21, 23). showed the relationship between knowledge management and entrepreneurship in the General Directorate of Youth and Sport of Khuzestan Province and Madhoshi and Sadati (2012) stated that sharing and application of knowledge directly and significantly affect entrepreneurship (23). However, mere gathering of knowledge in organizations cannot directly make for organizational entrepreneurship (23). The results of this study are also consistent with the findings of Wenhui and Zhen (2011) who believed that a successful knowledge management model was implemented and applied in Beijing Olympics 2008 (27). Knowledge management-sport management model is an innovative and creative model based on knowledge for holding great sporting events which includes four components of governance, knowledge management, organizing committee, and massive investment. This model not only offers suitable solutions for different problems in stages before and after applying for hosting but also owns predictor events during the holding of competitions. Khodayari and Tojari (2006) also showed that Physical Education students who had more knowledge to start entrepreneurship had a great need to learn and start entrepreneurship (28). Amalia and Nugroho (2011) stated that a successful knowledge management is based on organizational innovations and technological innovations in multinational corporations (29). O'Reilly and Knight (2007) believe that knowledge management is one of the most important pillars of sport organizations, as the custodians of sport in every country in the third millennium, for acquisition of organizational effectiveness and survival (30). Raesi et al. (2014) and Omidi, Tondnevis, and Mozafari (2013) reported the relationship between knowledge management and organizational effectiveness in sport organizations $(19,20)$. The results of the present study are consistent with the findings of Madhoushi et al. (2011) point out that creation of new knowledge can change the supply of organizational knowledge and quantitatively and qualitatively increase the existing knowledge aimed at idea creation and innovation (10). Knowledge-based view suggests that knowledge gathering activities (acquisition, creation, and storage of knowledge) increase the ability of organizations in brainstorming (idea creation) and innovation (31).

Sarin and McDermott (2003) state that more capable organizations that acquire knowledge from inside and outside the 
organization can discover more opportunities and develop innovative products and services (32). A study was conducted by Koshki Jahromi and Boudlaie (2010) in Iran Khodro Company entitled "The relationship between organizational factors of knowledge management and corporate entrepreneurship". Their findings revealed a significant and positive relationship between these variables in Iran Khodro Company. In other words, knowledge management can be regarded as a basis for the emergence of corporate entrepreneurship ((33). Farhangi and Safarzadeh (2006) found a relationship between components of organizational communications and components of entrepreneurship (the same as components in the present study). Their results showed that that there is significant and positive relationship between all three stages of corporate entrepreneurship and components of organizational communications (communication channels, communication content, communication pathways, communication styles) (24). The results of a study by Samadian, Alavi, and Balal (2011) showed that participation in knowledge, organization of knowledge, application of knowledge, evaluation of knowledge performance, discovery of knowledge, knowledge creation affects the creativity of employees of Tehran Broadcasting Organization (34). In another study conducted by Madhoshi and Sadati (2012) on 164 small and medium businesses entitled "The effects of knowledge management strategies on the relationship between market-orientation and market innovation", the results suggest that market-orientation both directly and indirectly affect the performance of innovation through knowledge management (23). So, knowledge management plays the role of a mediator between market-orientation and market innovation.

Kelley, Peters, and O'Connor (2009) studied the effects of entrepreneurial orientation and knowledge management capabilities on organizational effectiveness in the presence of social capital as a mediator and found that entrepreneurial orientation and knowledge management capabilities have a positive impact on innovation in products and processes and generally on organizational effectiveness and also stated that social capital modifies the effect of entrepreneurial orientation and knowledge management capabilities on organizational effectiveness (35). Li et al. (2009) studied how entrepreneurial orientation plays the role a mediator in the relationship between knowledge management and innovation in 607 Chinese enterprises and concluded that knowledge sharing within an organization leads to application of knowledge and innovation. They also stated that it is entrepreneurial orientation which plays the role a facilitator in organizations and maximizes the effect of knowledge sharing on application of knowledge and innovation (36).

According to the results of the correlation coefficient between knowledge management and entrepreneurship and as the relationship between these two variables was confirmed, managers of sport organizations should assume that knowledge management is one of the empowerments of entrepreneurship. If sport managers are interested in entrepreneurial activities, knowledge management should be viewed as one of the top priorities and must be taken into account in all major decisions. Additionally, it is necessary that managers, supervisors, and experts pursue this issue at all levels of sport organizations as a top priority and with predetermined plans.

\section{REFFRENCES}

1. Edgar Serna M. Maturity model of Knowledge Management in the interpretativist perspective. International Journal of Information Management. 2012;32(4):365-71. 
2. Khodabandehlou M, Azadikhah Salimi M, Heidari A. The impact of IT on knowledge management function. Sipa Thought Developer. 2012:68-70 [Article in Farsi].

3. Chen Y-Y, Huang H-L. Knowledge management fit and its implications for business performance: A profile deviation analysis. Knowledge-Based Systems. 2012;27(0):262-70.

4. Liao S-H, Wu C-c. System perspective of knowledge management, organizational learning, and organizational innovation. Expert Systems with Applications. 2010;37(2):1096-103.

5. Salkhi S, Ashouri T, Boroumand MR, Fazli A, Darzi The Impact of Knowledge Sharing on Entrepreneurship in Sport Organizations. Indian J Sci Res. 2014;7(1):955-8.

6. Hooshmand H, Mirafzal S, Rezaei NJ. Development of an Assessment Model for Knowledge Management in Knowledge-Based Organizations Study of University of Qom. Roshd-E-Fanavari. 2014;10(38):65-77 [Article in Farsi].

7. Nazari S, Biokani J, Karimi S, Rezaei K. The knowledge management, implications and models. First National Conference of Business; Hamedan, Iran: University of BoAli Sina; 2014 [Article in Farsi].

8. Ashouri T, Salkhi S, Boroumand MR, Fazli A, Darzi. The Impact of Knowledge Management on Competitive Opportunities Discovery in Sport Organizations. Journal of Applied Sciences Research. 2014;10(4):345-52.

9. Mosaheb Z, Khaksar D. Entrepreneurship is a solution for the improvement of organizational productivity and development. First National Conference of Business; Hamedan, Iran: University of BoAli Sina; 2014 [Article in Farsi].

10. Madhoushi M, Sadati A, Delavari H, Mehdivand M, Mihandost R. Entrepreneurial orientation and innovation performance: The mediating role of knowledge management. Asian Journal of Business Management. 2011;3(4):310-6.

11. Adnani M. The impact of knowledge management on organizational entrepreneurship. First National Conference of Business; Hamedan, Iran: University of BoAli Sina; 2014 [Article in Farsi].

12. Shane S, Venkataraman S. The Promise of Entrepreneurship as a Field of Research*. In: Cuervo Á, Ribeiro D, Roig S, editors. Entrepreneurship: Springer Berlin Heidelberg; 2007. p. 171-84.

13. Rezaei M. The need to develop a organizational knowledge map. Sipa Thought Developer. 2012:73-5 [Article in Farsi].

14. Hall JK, Daneke GA, Lenox MJ. Sustainable development and entrepreneurship: Past contributions and future directions. Journal of Business Venturing. 2010;25(5):439-48.

15. Quaddus $\mathrm{M}, \mathrm{Xu}$ J. Adoption and diffusion of knowledge management systems: field studies of factors and variables. Knowledge-Based Systems. 2005;18(2-3):107-15.

16. Kia M, Nasaj S. A new look at entrepreneurship training. Rooyesh. 2006;4(15):16-21 [Article in Farsi].

17. Radfar R, Rezaeimalek N, Rezaeimalek M. Evaluation Improving Financial Operations by Implementing Knowledge Management System. Management Accounting. 2015;7(2):33-46 [Article in Farsi].

18. Vazifehdust H, Foroughnejad H, Khoshnood M. Effects of Strategic Knowledge Management on Innovation and Performance of Registered Brokerage Firms of Tehran Stock Exchange. Journal of Accounting Knowledge And Management Auditing. 2014;3(9):161-73 [Article in Farsi].

19. Omidi A, Tondnevis F, Mozafari SAA. The Relationship between organizational culture with knowledge management effectiveness and organizational effectiveness among selected sport organizations of Iran. Research in Sport Management and Motor Behavior. 2013;2(4):87-103 [Article in Farsi].

20. Raesi M, Hosseini E, Talebpoor M, Nazari V. The Fit of Regression Equation of Knowledge Management and Organizational Effectivenss in Iran Selected Sport Organizations. Journal of Sport Management. 2014;5(4):47-65 [Article in Farsi].

21. Nasrollahi M, Khaksar M, Farhadi F, Eidar S. The impact of knowledge management on organizational entrepreneurship in General Office of Sports and Youth in Khozestan Province. International Conference on Management, Challenges and Solutions; Shiraz, Iran2013 [Article in Farsi].

22. Khosravi M, Esmaili M. Studying the Relationship between Knowledge Management and Organizational Entrepreneurship (Case Study: Labor and Social Affairs Department of Qom). Journal of Basic and Applied Scientific Research. 2013;3(7):643- 50.

23. Madhoshi M, Sadati A. The impact of knowledge management on organizational entrepreneurship (CASE STUDY: small and middle businesses of East Caspian). Journal of Entrepreneurship Development. 2012;4(12):7-26 [Article in Farsi].

24. Farhangi AA, Safarzadeh H. Designing and Defining an Organizational Communication Model in Entrepreneurship Process (Focus on Distribution Industry). Commercial Strategies. 2006;1(14):1-20 [Article in Farsi].

Ashouri, T., Boroumand, M. R. (2014). Ann Appl Sport Sci, 2(3): 41-50. 
25. Mokhtari M, Bayekolaei, Pourlahiji T, Salarian M. the relationship of knowledge management with organizational entrepreneurship-based on recent 5 years research. First National Conference of Business; Hamedan, Iran: University of BoAli Sina; 2014 [Article in Farsi].

26. Ju TL, Li CY, Lee TS. A contingency model for knowledge management capability and innovation. Industrial Management \& Data Systems. 2006;106(6):855-77.

27. Wenhui $\mathrm{H}$, Zhen Z. Innovation of management model of sport event based on knowledge management. 6th International Conference on Product Innovation Management (ICPIM); 16-17 July 2011; Wuhan, China: IEEE; 2011. p. 644 - 9.

28. Khodayari A, Tojari F. Examination of Enterpreneurs Readiness in Sport Arena: Preliminary Analysis of The Entrepreneur Scales. Research on Sport Science. 2006;4(10):73-88 [Article in Farsi].

29. Amalia M, Nugroho Y. An innovation perspective of knowledge management in a multinational subsidiary. Journal of Knowledge Management. 2011;15(1):71-87.

30. O'Reilly NJ, Knight P. Knowledge management best practices in national sport organisations. International Journal of Sport Management and Marketing. 2007;2(3):264-80.

31. Gold AH, Malhotra A, Segars AH. Knowledge Management: An Organizational Capabilities Perspective. J Manage Inf Syst. 2001;18(1):185-214.

32. Sarin S, McDermott C. The Effect of Team Leader Characteristics on Learning, Knowledge Application, and Performance of Cross-Functional New Product Development Teams. Decision Sciences. 2003;34(4):707-39.

33. Koshki A, Jahromi., Boudlaie H. Correlation between organizational factors of knowledge management with intrapreneurship. First International Congress of Management and Inovation; Shiraz, Iran: Shiraz University; 2010 [Article in Farsi].

34. Samadian A, Alavi S, Balal S. Affect On the Rate of Knowledge Creation the Staff of IRIB, Tehran Province. Journal of Cultural Management. 2011;5(11):65-74 [Article in Farsi].

35. Kelley DJ, Peters L, O'Connor GC. Intra-organizational networking for innovation-based corporate entrepreneurship. Journal of Business Venturing. 2009;24(3):221-35.

36. Li Y, Liu X, Wang L, Li M, Guo H. How entrepreneurial orientation moderates the effects of knowledge management on innovation. Systems Research and Behavioral Science. 2009;26(6):645-60. 
تازههاى علوم كاربردى ورزش

مقاله اصيل

دوره دوم، شماره سوم

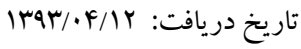

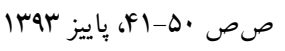

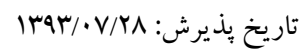

\section{رابطه مديريت دانش با فر آبند كار آفرينى در سازمان هاى ورزشى}

اتقى عاشورى*، 'محمد رضا برومند

ا. كارشناسى ارشد مديريت ورزشى، دانشكده تربيتبدنى و علوم ورزشى، دانشكاه شمال، آمل، ايران.

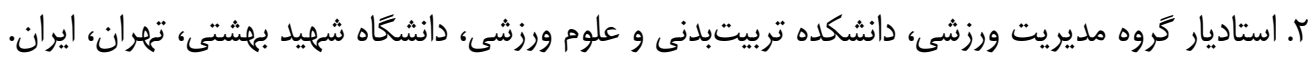

جكيده

در دنياى رقابتى امروز سازمانهايى مىتوانند به مزيت رقابتى پايدار دست يابند كه با ايجاد بسترهاى لازم از فرآيند كار آفرينى يشتيبانى كند. يكى

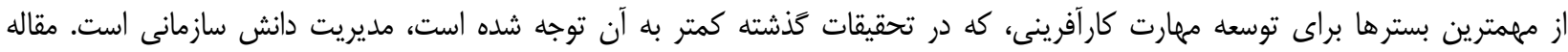

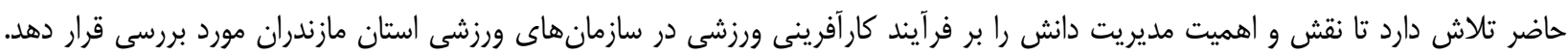
بدين منظور •هم نفر از مديران و كاركنان سازمانهاى ورزشى به عنوان نمونه در تحقيق شركت كردند. براى جمعآورى اطلاعات از دو

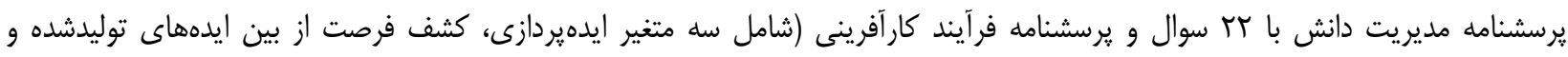
بجرهبردارى از ايدهها) با هـ سوال استفاده شد. نتايج نشان داد بين مديريت دانش و فرآيند كارآفرينى رابطه معنىدارى مشاهده شده است

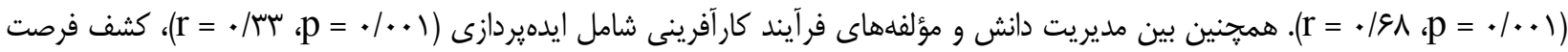

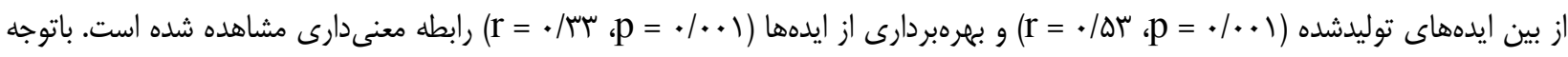
به نتايج تحقيق، توجه به مديريت دانش بطور سيستمى مى تواند سازمان را در ايدهيردازى، كشف فرصت ازه از بين ايدههاى توليدشده و بهرهبردارى

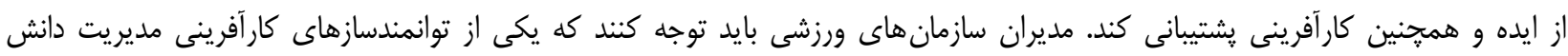

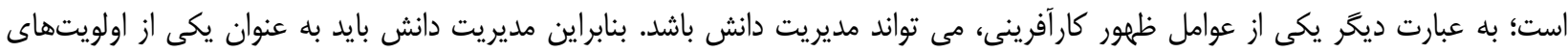
اصلى و بله صورت برنامهريزى شده توجه شود. وازَّان كليدى: مديريت دانش، ايدهيردازى، كشف فرصت، بهرهبردارى، كارآرينى، سازمانهاى ورزشى.

ت ${ }^{*}$ - نوسنده مسئول:
يست الكترونيك: t.ashouri86@yahoo.com 
